\title{
QUANTIFICATION OF THE INTERDEPENDENCE OF INNOVATION ABILITY AND COMPETITIVENESS OF THE SOUTHEAST EUROPEAN COUNTRIES
}

\author{
Slobodan Cvetanović* \\ Faculty of Economics, University of Niš, Niš, Republic of Serbia
}

\author{
Aleksandar Kostić \\ Faculty of Economics, University of Kosovska Mitrovica, Republic of \\ Serbia \\ Vukašin Šušić \\ Faculty of Economics, University of Niš, Nišs, Republic of Serbia
}

\begin{abstract}
Based on the data of the World Economic Forum, the individual impact of innovation capacity on the competitiveness of eleven countries in Southeast Europe in the period 2017-2019 was quantified by analyzing rank and index values and using the method of correlation analysis. The obtained results showed a significant relationship between the observed countries' ranks of innovation and competitiveness in the observed time interval. The results also showed a direct link between the index of innovation ability and global competitiveness when economic development is predominantly based on the so-called platform of the fourth industrial revolution. This implies the necessity for an efficient innovation policy in the countries of Southeast Europe since the improvement of a country's innovation capacity has a stimulating effect on the growth of their competitiveness.
\end{abstract}

Key words: innovation capacity, competitiveness, countries of Southeast Europe, economic development, the fourth industrial revolution

JEL classification: 032 , 052

*prof.cvet@gmail.com 


\section{KVANTIFIKACIJA MEĐUZAVISNOSTI SPOSOBNOSTI INOVIRANJA I KONKURENTNOSTI ZEMALJA JUGOISTOČNE EVROPE}

Sažetak: Na osnovu podataka Svetskog ekonomskog foruma, pojedinačni uticaj kapaciteta za inoviranje na konkurentnost jedanaest zemalja Jugoistočne Evrope u periodu od 2017. do 2019. godine je kvantifikovan putem analize dostignute pozicije, kao i vrednosti indeksa, uz primenu korelacione analize. Dobijeni rezultati ukazuju na postojanje statistički značajne povezanosti između dostignute pozicije, kada je reč o inovativnosti posmatranih zemalja, i konkurentnosti tokom posmatranog vremenskog perioda. Rezultati takođe ukazuju na direktnu vezu između indeksa inovacione sposobnosti $i$ globalne konkurentnosti u slučaju kada se privredni razvoj pretežno zasniva na takozvanoj platformi četvrte industrijske revolucije. Pomenuto ukazuje na potrebu za efikasnom politikom inoviranja u zemljama Jugoistočne Evrope, s obzirom na to da unapređenje inovacionog kapaciteta zemlje ima stimulativni efekat na porast njene konkurentnosti.

Ključne reči: kapacitet za inoviranje, konkurentnost, zemlje Jugoistočne Evrope, privredni razvoj, četvrta industrijska revolucija

\section{INTRODUCTION}

The increasingly pronounced process of globalization of the world economy led by the fourth industrial revolution creates new opportunities for improving the competitiveness of countries, but also increasingly complex challenges and requirements, especially in the field of strengthening the innovation capacity of countries as one of the primary drivers of sustainable national competitiveness (Philbeck \& Davis, 2019; Prisecaru, 2016). This undoubtedly happens due to the strengthening of innovation capacity in the function of intensifying desirable structural changes and creating conditions for dynamic economic growth, i.e., improving national competitiveness as a basis for long-term sustainable development in increasingly complex business challenges (Shwab, 2016; Sredojević, 2016).

Nowadays, there is a constant flow of expanding the division of labor in the world of globalization, which creates space for the processes of exchange and improving the competitiveness of companies in domestic and foreign markets (Peleckis, 2016). The current level of economic development requires many countries to focus on qualitative factors to increase their competitiveness, among which the improvement of innovation capacity stands out (Kordos, 2016). 
As economic development is not predetermined and does not happen by itself and in all countries, proactive attempts are important to initiate and maintain the development process (Bazić, 2017). Globalization and the fourth industrial revolution have brought about new opportunities and disruptions, increasing the development gap between different economies. Bearing that in mind, in 2018, the World Economic Forum presented the Global Competitiveness Index 4.0. as a new economic roadmap, based on forty-year-long experience in monitoring and comparing long-term competitiveness factors (Shwab, 2018).

Although economic analysts have been interested in careful consideration of the categories of innovative potential and competitiveness of countries over the last twenty years, the fact is that these are still insufficiently researched categories and that there is a large number of open questions regarding their quantification (Dragičević, 2012). Numerous gaps and ambiguities are especially noticeable when exploring the interrelationship between the categories of innovation capacity and competitiveness of countries. The World Economic Forum data on the values of the Global Competitiveness Index 4.0 and its components enable the analysis of the innovation capacity impact of individual countries on their national competitiveness in the selected three-year period (Shwab, 2018).

Amid fast technological progress, political restriction, and slow economic recovery, it is crucial to define, evaluate, and include new directions for economic development and economic success (Harvey, 2017).). In economic theory and practice, it is possible to distinguish two approaches to measuring the competitiveness of countries. The first is based on productivity growth, while the second centers on quantifying the effects of the observed economy in international trade (Despotović, Cvetanović \& Nedić, 2016).

Recently, especially at the time of the development of Industry 4.0, as a tool for quantifying macro-competitiveness, the composite indicator Global Competitiveness Index becomes significant. Its calculation presupposes a consistent theoretical basis for the concept of competitiveness, the selection of individual indicators, and the purposeful use of weight systems and appropriate aggregation procedures.

In addition to productivity, which is the most critical determinant of long-term growth and income, the Global Competitiveness Index 4.0 includes the significance of the most important factors of productivity growth in the era of the fourth industrial revolution. Viewed in this light, the Global Competitiveness Index 4.0 is a very respectable way to evaluate them. The key findings summarized in the new tool and its results were revealed by analysis at 
the global, regional and national levels. One of the leading international institutions researching the competitiveness of countries is the World Economic Forum. This organization views national competitiveness as the ability of the national economy to create a sustainable level and quality of life and defines it as "a set of institutions, policies, and factors that determine a country's level of productivity. The level of productivity then determines the sustainable level of prosperity that the economy can achieve (Schwab, 2016).

Based on extensive data collection efforts, the Global Competitiveness Index 4.0 provides new insights into the factors whose importance grows with the fourth industrial revolution's development (human capital, innovation, resilience and agility). The new concepts refer to an entrepreneurial culture, companies that accept disruptive ideas, companies' cooperation with several stakeholders, critical thinking, a system of promotion, trust (Lee et al., 2018). These concepts, in some way, complement traditional components (ICT and physical infrastructure, macroeconomic stability, property rights, years of education).

\section{RESEARCH METHODOLOGY}

This paper deals with categories of innovative potential and competitiveness of countries because the innovative capacity of the economy reflects the country's potential to produce goods based on the creation of new knowledge and skills, and the country's competitiveness shows the ability to use national resources in a way that contributes most to real GDP growth and living standards. Emphasis is placed on quantifying the impact of innovation capacity on the competitiveness of Southeast European countries (Albania, Bosnia and Herzegovina, Bulgaria, Montenegro, Croatia, Greece, North Macedonia, Moldova, Romania, Serbia and Turkey) in the era of the fourth industrial revolution.

The research aims to find an acceptable answer to the question of whether there is a mutual connection between these macroeconomic categories of the group of countries to which the Republic of Serbia belongs, which, in addition to certain theoretical values, could potentially have great practical significance in designing own development policies.

In seeking an answer to the question of whether the growth of innovation capacity of these countries ceteris paribus means improving their competitiveness, and starting from the subject and objectives of the research, the paper starts from the following research hypotheses: 
H1: There is a statistically significant relationship between the rank of innovation capacity and competitiveness of the countries of Southeast Europe, and

H2: There is a statistically significant relationship between the achieved level of innovation capacity and the competitiveness of the countries of Southeast Europe.

To prove the previously defined hypotheses, the basic method applied in the research is a comparative analysis that compares the overall international competitiveness of Southeast European countries and their innovation capacity. The impact of innovation capacity (measured by the innovation capacity index) on the competitiveness (measured by the values of the Global Competitiveness Index 4.0) of 11 countries in Southeast Europe in the three-year period from 2017 to 2019 will be investigated by using statistical-econometric methods (correlation analysis). The research will be conducted on the basis of data taken from the World Economic Forum database.

The degree of functionality between the two variables in the paper is measured by correlation (correlation coefficient). The numerical expression of the degree of functionality between two characters will use the Pearson correlation coefficient - $r$ or the Spearman sequence correlation coefficient - R. The coefficients require that the correlated selections have at least an approximately normal range of distribution and selection $\mathrm{n} \sim 30$.

A significance test will verify correlation coefficients. The test answers the question of whether the obtained results can be generalized to the whole basic set. Therefore, if there is a statistically significant functionality between $\mathrm{X}$ and $\mathrm{Y}$, hypothesis $\mathrm{H} 1$ on the independence of the observed indicators is rejected in favor of the alternative hypothesis if the value of $p$ is $<\alpha(0.05)$.

To confirm hypothesis $\mathrm{H} 2$, we determined whether the observed degree of connection can be generalized to the whole basic set, i.e., whether there is a statistically significant functionality between the index values being compared. Therefore, in the paper at the level of significance $\alpha=0.05$, the correlation coefficient test tests the hypothesis that there is a statistically significant functionality between the innovation capacity index and competitiveness index. 
90 | QUANTIFICATION OF THE INTERDEPENDENCE OF INNOVATION ABILITY AND COMPETITIVENESS OF THE SOUTHEAST EUROPEAN COUNTRIES

\section{COMPETITIVENESS}

\subsection{MEASURING COMPETITIVENESS IN INDUSTRY 4.0}

During the fourth industrial revolution, the World Economic Forum measures the national competitiveness of countries using the Global Competitiveness Index 4.0 (GCI 4.0), which offers a detailed overview of the factors and characteristics that determine profitability, potential and human progress. The index is based on the economic theory of growth and aims to measure the drivers of total factor productivity (TFP), i.e., the part of economic potential that is not explained by the growth of factors of production. Total factor productivity can be interpreted in the way how to use production factors wisely and which is the main determinant of long-term economic growth. Simply put, total factor productivity shows how efficiently are the units of labor and capital combined to create production.

The Global Competitiveness Index 4.0 is an annual indicator obtained by aggregating a large number of individual indicators that quantify specific dimensions of competitiveness at the national level. It allows economic policymakers to assess their progress against a range of productivity factors. It encompasses 103 individual indicators, obtained based on data collected from international organizations (usually national statistical organizations) and from a study led by the World Economic Forum's Executive Opinion Survey, whose goal is to supplement data that cannot be obtained from official statistical sources (these are the so-called soft data). All indicators that make up the Global Competitiveness Index 4.0 are organized into 12 'pillars': Institutions; Infrastructure; Application of ICT; Macroeconomic stability; Health; Skills; Product market; Job market; Financial system; Market size; Business dynamics; and Innovation Capability.

The Global Competitiveness Report of the Fourth Industrial Revolution era is made to provide policymakers, business leaders and other stakeholders worldwide the possibility to establish their growth and development strategies that are in line with the scope of the Fourth Industrial Revolution. At the same time, this report calls for economic agents to get involved in a holistic and fast process of building a competitive economy, which guarantees to raise people's living standards.

The Global Competitiveness Index 4.0 offers a new assessment of progress ranging from 0 to 100 . The 100 limit corresponds to the target set for each indicator and is usually a policy objective. The aim of each country should be to maximize its results on each indicator, with the stated value talking about the 
country's current progress in relation to the border and the remaining distance from it. From this point of view, it becomes evident that competitiveness is not a zero-sum game between countries but is attainable by all countries.

The affirmation of the fourth industrial revolution creates, among other things, the acceleration of the innovation cycle and causes faster obsolescence of business models. Continuous innovation makes way for new entrants and reduces obstacles to technology transfer or upheaval and requires the management of frequent disruptions in the industry. To address these challenges, stakeholders in an expanding economy should establish an appropriate tool to diminish the risk of new financial crises and manage the socio-economic effects of innovation. In other words, successful economies in the era of the fourth industrial revolution must:

- Be resilient, build economic mechanisms to prevent financial crises or mass unemployment, and respond to external shocks.

- Be agile, accept change before resisting it. Companies, policymakers and workers need to adapt quickly and take advantage of opportunities to produce goods or provide services in new ways.

- Build an innovation ecosystem in which innovation is encouraged at all levels and where all stakeholders contribute to creating the best conditions for creating new ideas, which will be funded and commercialized as new products and services.

- Adopt a people-oriented approach to economic development. This means knowing that human capital is necessary to create prosperity and that any policy that affects the potential of the human factor will reduce economic growth in the long run. Consequently, the policy created will have to ensure that the speed of change and the introduction of new technologies eventually turn into better living conditions (Schwab, 2018).

Although the same goal is maintained as with the previous index, IGK 4.0 reconsiders the determinants of productivity and its quantification. The new methodology encompasses all factors identified in the literature and by experts as important for productivity in the 4IR era. 


\subsection{COMPETITIVENESS OF COUNTRIES IN 2019}

In 2019, the Global Competitiveness Report published the latest data on the values of the Global Competitiveness Index 4.0., which shows competitiveness and provides insight into the economic prospects of 141 countries, which makes up $99 \%$ of world GDP. The report is designed to help policymakers, business leaders, and other stakeholders shape their economic strategies in the fourth industrial revolution era.

Results of the Global Competitiveness Index 4.0. for 2019 point to a deep competitiveness deficit that should be addressed urgently to bring back productivity and growth to improve living standards. The obtained results indicate that, on average, most economies are still far from the "limit" of competitiveness - the overall ideal in all factors of competitiveness. The average GCI score for 141 analyzed economies is 60.7 index points, which means that the "distance to the border" is almost 40 points. The effect also differs among the 12 pillars of the index. At 9 of the 12 pillars, the average global gap is more than 30 points. Developed economies manage compatibly better than the rest of the world, but all together, they still have 30 points less than the border. Singapore, the best player in the overall ranking, still does not score 15 points from the ideal (Schwab, 2019).

Experts from the World Economic Forum pointed out that technology and innovation are the economy's DNA, which is a challenge. However, according to these authors, an even greater challenge is how to ensure that governments, i.e., policymakers, provide that as many citizens in their countries benefit from the development of technology and innovation. Therefore, the necessity of applying a holistic approach through investments in human capital and measures to mitigate the unintended harmful effects of technological progress on income distribution and social cohesion is pointed out. It is emphasized that in the so-called Schumpeter process of "creative destruction", creativity must be encouraged, which indicates the need for efficient management of the process of "destruction". Increased job insecurity, skills gap, excessive market concentration, corrosive effects on social fabric, regulatory loopholes, data privacy issues and cyber warfare are just some of the potential adverse effects that governments must mitigate to improve competitiveness and have long-term sustainability.

In the Global Competitiveness Report for 2019, the authors paid special attention to improving innovation. The results obtained show that technology management is not sufficiently aligned with modernization in most countries, including some of the largest and most modern. That is why countries need to 
improve the adaptability of talent; that is, to enable their workforce to contribute to the process of creative destruction. Talent adaptability also requires a wellfunctioning labor market that protects employees, not jobs. The report reveals that in several countries with significant innovation and technological potentials, such as Korea, Italy, France and Japan, insufficient talent development can increase the risk of negative social consequences. Emerging economies with growing innovation potentials, such as China, India and Brazil, also need to better balance technological integration and investment in human capital.

The report shows that just focusing on economic growth without an equal focus on making growth inclusive and sustainable for the environment can have major consequences on the planet and its inhabitants. Rapid changes in climate conditions are already affecting hundreds of millions of people worldwide, and people under the age of 60 will likely witness its radical destabilizing effects on Earth. Simultaneously, growing inequality, insecurity and lack of social mobility deteriorate the social balance with a growing sense of injustice, perceived loss of identity and dignity, weakening the social structure, undermining trust in institutions, dissatisfaction with political processes and erosion of the social contract.

It has become clear to the authors of the report that environmental, social and economic programs can no longer be implemented separately and in parallel: they must be integrated into a single sustainable and inclusive growth plan. In this approach, perceived trade-offs between economic, social and environmental factors can be mitigated by adopting a holistic and longer-term approach to growth. This means addressing spillover effects and external, positive and negative, intentional or unintentional, economic policies beyond the direct goals they want.

What is more, it is stated that the different degrees and speeds at which countries adopt such a holistic approach to growth are reflected in the fact that countries at a similar level of competitiveness achieve very different environmental and social outcomes. For example, Sweden, Denmark and Finland have not only become among the most technologically advanced, innovative and dynamic economies in the world, but they also provide better living conditions and better social protection. For this reason, they are more cohesive and more sustainable than other countries.

The basic message given in the Global Competitiveness Report for 2019 is that economic growth is still a key source and factor in improving people's living 
standards and quality of life. In addition, research into the relationship between competitiveness, prosperity and environmental sustainability shows there is no balance between competitiveness, the creation of fairer societies that provide opportunities for all and the transition to an environmentally sustainable socioeconomic system. Therefore, it is clear that a new inclusive and sustainable system requires courageous leadership and dynamic decision-making, often in areas where economists and government law professionals cannot use any previous experience.

The Global Competitiveness Index 4.0 results for 2019 indicate that the largest number of countries is significantly away from the "limit" of competitiveness, as the imaginary values of all competitiveness factors. The average score of 60 confirms that many economies in the world should include measures that are in the function of accelerating the long-term economic growth rate and preventing long-term imbalances, thus creating conditions for improving the living standards of the population. In addition, based on the Global Competitiveness Index results, it can be concluded that countries have a mixed effect in 12 pillars. Perennial open issues of economic development, such as the low quality of institutions, have remained a very pronounced limiting factor in improving the competitiveness of countries at the global level. Nevertheless, the results of the Global Competitiveness Index 4.0 in 2019 showed that there are economies that have achieved good results in improving global competitiveness.

\section{INNOVATION ABILITY AS A FACTRO OF COMPETITIVENESS IN NIDUSTRY 4.0.}

Innovation capacity is essential for economically developed, resource-efficient, and competitive countries in the global market (Kaynak, Altuntas \& Dereli, 2017). Innovation contributes to creating a competitive advantage in ambiguity, creating a link between a company's performance in the marketplace and new products. New products help maintain market share and improve profitability. Innovations improve the competitiveness of companies by improving non-price factors, such as design, quality, individualization, and by replacing obsolete products (shortening the product life cycle). Also, process innovations lead to a shortening of production time and acceleration of the development of new products, thus creating an advantage over competitors (Cvetanović \& Nedić, 2018).

In modern business, connecting companies into innovation clusters is becoming an increasingly important factor in developing innovative activities and improving the competitiveness of companies (Habanik, Kordos \& Hostak, 2016). Unlike traditional clusters, innovation clusters represent a system of 
close relations not only between companies, their suppliers and customers, but also include knowledge institutions, including research centers, universities, scientific research institutes, etc. As a generator of new knowledge and innovation, they provide a high level of competitiveness (Balcerzak \& Pietrzak, 2016).

Innovation is an important factor of competitiveness because it allows existing knowledge and technologies to be used to a greater extent and is a sound basis for developing new knowledge and technology (Cvetanović, Nedić \& Despotović, 2018). In the modern economy characterized by the development of the fourth industrial revolution, companies must create and develop top products and processes to maintain a competitive advantage and develop activities that create greater added value, thus solving economic and wider social problems (Hadad, 2015).

The development and implementation of innovation require an environment suitable for innovative activities and supported by both the public and private sectors. This means that appropriate investments in research and development are needed, especially by the private sector, that there are high-quality scientific research institutions that can create the basic knowledge needed to build new technologies, that there is broad cooperation in research and technological development between the university and the economy and that there is the effective protection of intellectual property (Bilas, Bošnjak \& Novak, 2018).

Keeping in mind the importance of previous factors for improving the competitiveness of an economy, the World Economic Forum experts recognized the importance of innovation and factors that determine innovation, so that innovation capacity is one of the 12 basic pillars of competitiveness measured by the Global Competitiveness Index 4.0.

The index (pillar) of innovation capacity measures: the quantity and quality of formal research and development, the extent to which a country's environment encourages cooperation, connectivity, creativity, diversity and competition in different visions and views, as well as the ability to turn ideas into new products and services.

Experts from the World Economic Forum further believe that countries that can create greater knowledge accumulation and that offer better opportunities for cooperation or interdisciplinarity tend to have a greater capacity to generate innovative ideas and new business models, which are seen as drivers of economic growth. 
The Innovation Capability Index consists of 10 sub-indices. The first factor that determines a country's innovation capacity is the diversity of the workforce. The value of this factor is based on a survey.

The second factor of innovation capacity measures the development of clusters and it is obtained in response to a survey question:" How developed and deep are the clusters in your country (geographical concentrations of companies, suppliers, manufacturers of related products and services and specialized institutions in a particular area)?"

The third factor refers to international cooperation in the field of inventions (patents) and is measured on the basis of the number of patent applications with co-inventors who are abroad per million inhabitants.

The fourth factor, which determines the ability to innovate, is the development of cooperation between several stakeholders. It was obtained based on the average score of three survey questions: "To what extent do people cooperate and share ideas in companies in your country?", "To what extent do the economy cooperate in sharing ideas and innovate in your country? "and "To what extent do the economy and universities cooperate in research and development in your country?"

The fifth factor of a country's innovation capacity is the number and quality of scientific publications, measured by an index that determines the number of publications and their citations at the national level.

The sixth factor of innovative capacity refers to the number of patent applications and is measured as the total number of family patent applications per million inhabitants.

The seventh factor of innovation capacity refers to the amount of investment in research and development $(R \& D)$ and is measured by the percentage share of $\mathrm{R} \& \mathrm{D}$ expenditures in GDP.

The eighth factor of innovation ability refers to the prominence, i.e., the recognition of research institutions, and is monitored on the basis of an index that measures the prominence and reputation of private and public research institutions.

The ninth factor of innovation ability refers to the sophistication of customers and is measured by the survey question: " On which basis do customers make purchasing decisions in your country?" 
The tenth factor that affects the ability to innovate is the application, i.e., the use of trademarks by companies, and is measured on the basis of the number of trademark applications per million inhabitants.

\section{RESULTS}

\subsection{THE IMPACT OF INNOVATION CAPACITY ON THE COMPETITIVENESS OF SOUTHEAST EUROPEAN COUNTRIES}

Quantification of the impact of innovation capacity on the competitiveness of the Southeast European countries in the period 2017-2019, based on their position (rank) on the global scale of competitiveness (according to the Global Competitiveness Index) and the global scale of innovative ability (according to the index of innovative ability), was conducted by applying correlation analysis.

This analysis will test the initial assumption of whether there is a statistically significant relationship between the position (rank) of innovation capacity and competitiveness of the Southeast European countries.

By testing the previous assumption, the dependence between the factors that build the innovation capacity and the overall competitiveness of 11 countries in Southeast Europe in the observed three-year period (from 2017 to 2019) will be examined. The selection consisted of 3 ranges in each of the 11 countries, i.e., the number of observations is $33(\mathrm{n}=33)$. Datasets have an approximately normal distribution, as seen from Shapiro-Wilk's p-value test.

The research first assessed the functionality, i.e., the degree of agreement between the ranking of the index that measures innovation opportunities and the cumulative rank of the global competitiveness index. As the value of the sequence correlation coefficient $-\mathrm{R}=0.93$, it can be concluded that there is a high degree of correlation between the ranking of the innovation capacity index and the cumulative competitiveness index.

This positive functionality is also shown in the chart below, where the growth of the rank of one indicator follows the growth of the rank of another indicator. The chart on the $\mathrm{x}$-axis shows the ranks of the innovation capacity index of the countries of Southeast Europe, and the y-axis shows the rank of the index of competitiveness of the observed countries. 
98 | QUANTIFICATION OF THE INTERDEPENDENCE OF INNOVATION ABILITY AND COMPETITIVENESS OF THE SOUTHEAST EUROPEAN COUNTRIES

Table 1

Ranking of Southeast European countries according to competitiveness and innovation capacity from 2017-2019

\begin{tabular}{|c|c|c|c|}
\hline Country & Year & $\begin{array}{c}\text { Competitiveness } \\
\text { (Rank) }\end{array}$ & $\begin{array}{c}\text { Innovative } \\
\text { Capability (Rank) }\end{array}$ \\
\hline \multirow{3}{*}{ Albania } & 2019 & 81 & 110 \\
\hline & 2018 & 76 & 91 \\
\hline & 2017 & 80 & 92 \\
\hline \multirow{3}{*}{ Bulgaria } & 2019 & 49 & 48 \\
\hline & 2018 & 51 & 48 \\
\hline & 2017 & 51 & 48 \\
\hline \multirow{3}{*}{$\begin{array}{c}\text { Bosnia and } \\
\text { Herzegovina }\end{array}$} & 2019 & 92 & 117 \\
\hline & 2018 & 91 & 114 \\
\hline & 2017 & 90 & 114 \\
\hline \multirow{3}{*}{ Greece } & 2019 & 59 & 47 \\
\hline & 2018 & 57 & 44 \\
\hline & 2017 & 53 & 43 \\
\hline \multirow{3}{*}{ Croatia } & 2019 & 63 & 73 \\
\hline & 2018 & 68 & 63 \\
\hline & 2017 & 66 & 62 \\
\hline \multirow{3}{*}{ Moldova } & 2019 & 86 & 109 \\
\hline & 2018 & 88 & 105 \\
\hline & 2017 & 87 & 98 \\
\hline \multirow{3}{*}{ North Macedonia } & 2019 & 82 & 97 \\
\hline & 2018 & 84 & 98 \\
\hline & 2017 & & \\
\hline \multirow{3}{*}{ Montenegro } & 2019 & 73 & 69 \\
\hline & 2018 & 71 & 74 \\
\hline & 2017 & 73 & 85 \\
\hline \multirow{3}{*}{ Romania } & 2019 & 51 & 55 \\
\hline & 2018 & 52 & 57 \\
\hline & 2017 & 52 & 61 \\
\hline \multirow{3}{*}{ Serbia } & 2019 & 72 & 59 \\
\hline & 2018 & 65 & 56 \\
\hline & 2017 & 70 & 65 \\
\hline \multirow{3}{*}{ Turkey } & 2019 & 61 & 49 \\
\hline & 2018 & 61 & 47 \\
\hline & 2017 & 58 & 47 \\
\hline \multicolumn{2}{|c|}{ Shapiro-Wilk's test p-values } & 0,0484648 & 0,00249516 \\
\hline
\end{tabular}

Note. WEF_GCI_4.0_2019_Dataset 


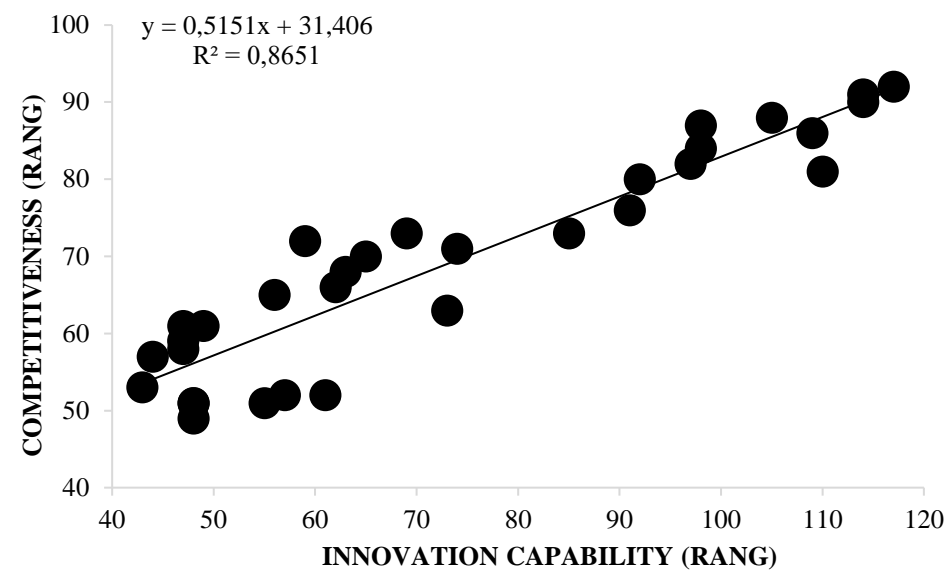

Figure 1. Correlation of the ranks of innovative ability and competitiveness of the countries of Southeast Europe in the period 2017-2019

Note. WEF_GCI_4.0_2019_Dataset

Table 2

Model 1: OLS, using observations 1-33 $(n=32)$

\begin{tabular}{lccccc}
\hline & Coefficient & Std. Error & t-ratio & p-value & \\
\hline Const & 31,4058 & 2,87136 & 10,9376 & $5,45 \mathrm{e}-012$ & $* * *$ \\
Inov & 0,515145 & 0,0371452 & 13,8684 & $1,38 \mathrm{e}-014$ & $* * *$ \\
\hline
\end{tabular}

\begin{tabular}{lrlr}
\hline Mean dependent var & 69,15625 & S.D. dependent var & 13,84502 \\
Sum squared resid & 801,7994 & S.E. of regression & 5,169782 \\
R-squared & 0,865067 & Adjusted R-squared & 0,860570 \\
F(1, 30) & 192,3331 & P-value(F) & $1,38 \mathrm{e}-14$ \\
Log-likelihood & $-96,94399$ & Akaike criterion & 197,8880 \\
Schwarz criterion & 200,8195 & Hannan-Quinn & 198,8597 \\
\hline
\end{tabular}

Note. WEF_GCI_4.0_2019_Dataset (Missing or incomplete observations dropped: 1; Dependent variable: GCI)

In order to confirm the accuracy of the previous assumption, it was investigated below whether the observed level of connectivity can be generalized to the 
whole basic set, i.e., whether there is statistically significant functionality between these ranks of innovative ability and competitiveness. At the significance level $\alpha=0.05$, the correlation coefficient significance test tested hypothesis $\mathrm{H} 1$ that there is a statistically significant functionality between the $\mathrm{X}$ and $\mathrm{Y}$ rankings, where $\mathrm{X}$ means innovation ranking and $\mathrm{Y}$ means competitiveness ranking.

Since the value of $\mathrm{p}$ is $\left(1,38.10^{-14}\right)<\alpha(0,05)$, it can be stated that the correlation is statistically significant, and thus confirms the hypothesis $\mathrm{H} 1$ that there is a significant correlation between the ranks of innovation and competitiveness of the observed countries of Southeast Europe in the period 2017-2019.

\subsection{THE IMPACT OF INNOVATION CAPACITY ON THE COMPETITIVENES OF SOUTHEAST EUROPEAN COUNTRIES}

Since changes in the ranking of non-Southeast European countries may also have an impact on the correlation in the ranking of countries according to innovation capacity and competitiveness indices, the assumption that verifies the correlation between the absolute value (ranging from 1 to 100) of the innovation capacity index and competitiveness index of Southeast European countries is examined in the part that follows.

The second assumption is based on the fact that during the observed period, there is a statistically significant functionality between the value of innovation capacity index and the value of the competitiveness index of the countries of Southeast Europe in the period 2017-2019.

The survey covers a total of three values (three years) of each country in Southeast Europe (except for Northern Macedonia, where data for 2019 are not available), i.e., the number of observations is $33(n=33)$. As the data have an approximately normal distribution and a relatively large range, the Pearson correlation coefficient was used for comparison.

In the first step, the functionality, the degree of coincidence of innovation capacity (values of the innovation capacity index) and competitiveness (values of the global competitiveness index) of a certain country in Southeast Europe and each observed year (from 2017 to 2019) are assessed. The correction coefficient $\mathrm{r}=0.916$ reflects a high degree of correlation between innovation capacity and competitiveness, i.e., the innovation capacity index and the Global Competitiveness Index. 
Table 3

Values of the index of innovation capacity and competitiveness of the Southeast European countries in the period 2017-2019

\begin{tabular}{|c|c|c|c|}
\hline Country & Year & Competitiveness & $\begin{array}{l}\text { Innovative } \\
\text { Capability }\end{array}$ \\
\hline \multirow{3}{*}{ Albania } & 2019 & 57,6 & 29,8 \\
\hline & 2018 & 58,1 & 31,7 \\
\hline & 2017 & 57,3 & 31,5 \\
\hline \multirow{3}{*}{ Bulgaria } & 2019 & 64,9 & 45,0 \\
\hline & 2018 & 63,6 & 43,9 \\
\hline & 2017 & 62,4 & 42,5 \\
\hline \multirow{3}{*}{$\begin{array}{l}\text { Bosnia and } \\
\text { Herzegovina }\end{array}$} & 2019 & 54,7 & 28,4 \\
\hline & 2018 & 54,2 & 28,2 \\
\hline & 2017 & 53,8 & 28,2 \\
\hline \multirow{3}{*}{ Greece } & 2019 & 62,6 & 45,1 \\
\hline & 2018 & 62,1 & 45,0 \\
\hline & 2017 & 61,8 & 45,3 \\
\hline \multirow{3}{*}{ Croatia } & 2019 & 61,9 & 37,8 \\
\hline & 2018 & 60,1 & 37,7 \\
\hline & 2017 & 60,1 & 37,6 \\
\hline \multirow{3}{*}{ Moldova } & 2019 & 56,7 & 29,9 \\
\hline & 2018 & 55,5 & 30,2 \\
\hline & 2017 & 54,6 & 30,6 \\
\hline \multirow{3}{*}{$\begin{array}{c}\text { North } \\
\text { Macedonia }\end{array}$} & 2019 & 57,3 & 31,8 \\
\hline & 2018 & 56,6 & 31,1 \\
\hline & 2017 & & \\
\hline \multirow{3}{*}{ Montenegro } & 2019 & 60,8 & 38,3 \\
\hline & 2018 & 59,6 & 34,9 \\
\hline & 2017 & 58,2 & 32,3 \\
\hline \multirow{3}{*}{ Romania } & 2019 & 64,4 & 42,3 \\
\hline & 2018 & 63,5 & 39,6 \\
\hline & 2017 & 62,2 & 37,6 \\
\hline \multirow{3}{*}{ Serbia } & 2019 & 60,9 & 40,2 \\
\hline & 2018 & 60,9 & 39,7 \\
\hline & 2017 & 59,2 & 37,1 \\
\hline \multirow{3}{*}{ Turkey } & 2019 & 62,1 & 44,5 \\
\hline & 2018 & 61,6 & 44,0 \\
\hline & 2017 & 61,4 & 43,6 \\
\hline \multicolumn{2}{|c|}{ ShapiroWilk'stest p-values } & 0,142987 & 0,00715512 \\
\hline
\end{tabular}

Note. WEF_GCI_4.0_2019_Dataset 
The positive functionality can also be seen in the chart below, where the innovation capacity index values are on the $\mathrm{x}$-axis and global competitiveness index values on the y-axis. It shows the existence of dependence between innovation and competitiveness.

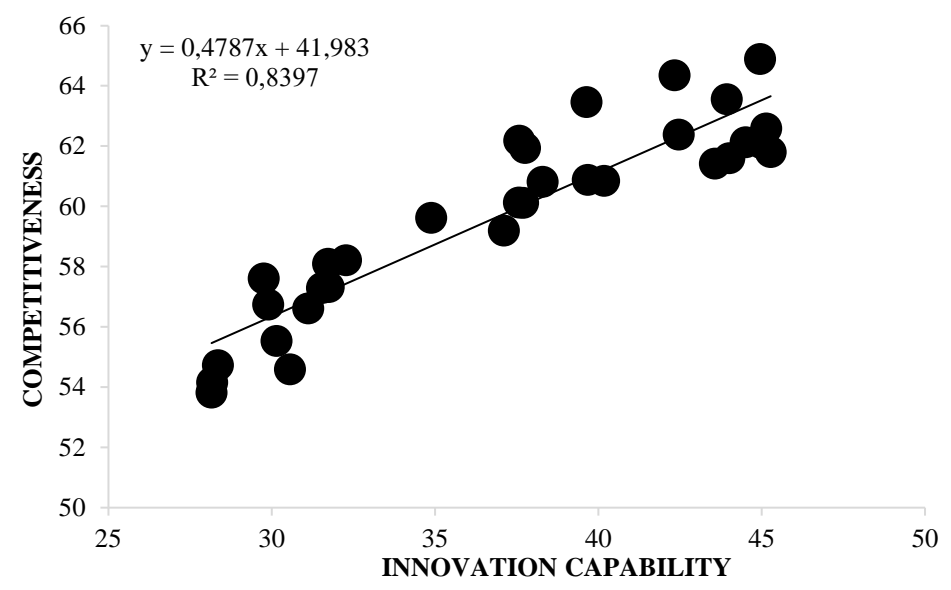

Figure 2. Correlation of the value of the innovation capacity index and the competitiveness index of the Southeast European countries in the period 20172019

Note. WEF_GCI_4.0_2019_Dataset

To confirm the previous assumption, we have to determine whether the observed degree of connection can be generalized to the whole basic set, i.e., whether there is statistically significant functionality between the index values.

At the significance level $\alpha=0.05$, the correlation coefficient significance test tested the hypothesis that there is a statistically significant functionality between the innovation ability index and the competitiveness index.

Since $\mathrm{p}=(1.85 \mathrm{e}-013)<\alpha(0.05)$, it follows that the correlation between the values of the innovation capacity index and the competitiveness index is statistically significant. This confirmed hypothesis $\mathrm{H} 2$. 
Table 4

Model 2: OLS, using observations 1-33 $(n=32)$

\begin{tabular}{lccccc}
\hline & Coefficient & Std. Error & t-ratio & \multicolumn{2}{c}{$p$-value } \\
\hline Const & 41,9831 & 1,43176 & 29,3226 & $1,21 \mathrm{e}-023$ & $* * *$ \\
Inov & 0,478707 & 0,0381801 & 12,5381 & $1,85 \mathrm{e}-013$ & $* * *$ \\
\hline \multicolumn{7}{c}{} & & & & \\
\hline Mean dependent var & 59,71126 & S.D. dependent var & 3,130635 \\
Sum squared resid & 48,68898 & S.E. of regression & 1,273957 \\
R-squared & 0,839748 & Adjusted R-squared & 0,834406 \\
F(1, 30) & 157,2049 & P-value(F) & $1,85 \mathrm{e}-13$ \\
Log-likelihood & $-52,12150$ & Akaike criterion & 108,2430 \\
Schwarz criterion & 111,1745 & Hannan-Quinn & 109,2147 \\
\hline
\end{tabular}

Note. WEF_GCI_4.0_2019_Dataset (Missing or incomplete observations dropped: 1; Dependent variable: GCI)

In general, in the countries of Southeast Europe, the innovation capacity index and the global competitiveness index are growing, which indicates the growth of both innovation and competitiveness of these countries. This, however, does not exclude the possibility that there is significant linear functionality among the other indices observed and the overall competitiveness index.

\section{CONCLUSION}

The impact of innovation capacity on the competitiveness of the countries of Southeast Europe in the period 2017-2019 was quantified based on their position (rank) on the global scale of competitiveness and the global scale of innovation ability by applying correlation analysis. The obtained results showed that there is a high degree of correlation between the ranking of the innovation capacity index and the aggregate global competitiveness index, as well as that the correlation is statistically significant, which confirms the existence of a significant relationship between innovation and competitiveness ranks of Southeast European countries in 2017-2019. 
Changes in the ranking of non-Southeast European countries may also impact the correlation in the ranking of countries according to innovation capacity and competitiveness. Therefore, the paper examines whether there is a statistically significant relationship between the attained level of competitiveness and innovation capacity of Southeast European countries based on correlations between the absolute value (ranging from 1 to 100) of the innovation capacity index and the competitiveness index of the Southeast European countries. The obtained result confirmed the existence of a high degree of correlation between innovation capacity and competitiveness, i.e., the innovation capacity index and the Global Innovation Index. The test of the significance of the correlation coefficient confirmed that the correlation is statistically significant, which confirmed the second assumption, i.e., that there is a statistically significant relationship between the achieved level of competitiveness and innovation capacity of Southeast European countries.

The research results show that the countries of Southeast Europe still lag significantly behind the average and most of the member states of the European Union and developed countries in the world. One of the reasons for this situation is the speed and quality of recovery of these countries from the negative effects of the economic crisis and the slow pace of implementation of structural changes. Simultaneously, the results of the conducted research indicate that to increase the level of competitiveness at the international level, it is important to intensively search for opportunities for the spread of innovations and innovative processes in these countries. Progress can be made in several areas, starting with the improvement of the business environment and the conditions for the development and application of innovations. To this end, governments in these countries should establish appropriate tools to support innovation, then various fiscal, monetary and other indirect measures to support companies in investing in research and innovation, etc. It is also important to connect academic and scientific institutions with the economy, as well as the development of human resources through the improvement of the educational system, etc.

\section{REFERENCES}

Balcerzak, A. P., \& Pietrzak, M. B. (2016). Quality of Institutions for Knowledge-based Economy within New Institutional Economics Framework. Multiple Criteria Decision Analysis for European Countries in the Years 20002013. Economics and Sociology, 9(4), 66-81. 
Bazić, J. (2017). Trendovi promena u društvu i obrazovanju koje generiše Četvrta industrijska revolucija. Sociološki pregled, 51(4) 526-546.

Bilas, V., Bošnjak, M., \& Novak, I. (2018). Konkurentnost zemalja članica Europske unije. Tranzition/Tranzicija, 20(42).

Cvetanović, S., \& Novaković, I. (2014). Inovacije $i$ održiva konkurentnost. Niš: Filozofski fakultet, Univerzitet u Nišu.

Cvetanović, S., \& Nedić, V. (2018). Inovacija kao razvojni resurs. Niš: Ekonomski fakultet, Univerzitet u Nišu.

Cvetanović, S., Nedić, V., \& Despotović, D. (2019). Inovacija, kvalitet $i$ konkurentnost. Niš: Ekonomski fakultet, Univerzitet u Nišu.

Despotović, D., Cvetanović, S., \& Nedić, V. (2016). Analysis of Innovativeness, as a Determinant of Competitiveness of the Selected European Countries. Industrija, 44(1) 89-111.

Dragičević, M. (2012). Konkurentnost: projekt za Hrvatsku. Zagreb: Školska knjiga.

Habanik, J., Kordos, M., \& Hostak, P. (2016). Competitiveness of Slovak economy and regional development policies. Journal of International Studiea, 9(1), 144-155.

Hadad, S. (2015). Analytic hierarchy process analysis for choosing a corporate social entrepreneurship strategy. Management \& Marketing, 10(3), 185-207.

Harvey, R. (2017). The "fourth industrial revolution»: potentials and risks for Africa. Retrivered from https://theconversation.com/the-fourthindustrial-revolution-potential-and-risks-for-africa75313

Kaynak, S., Altuntas, S., \& Dereli, T. (2017). Comparing the innovation performance of EU candidate countries: an entropy-based TOPSIS approach. Economic Research, 30(1), 31-54.

Kordos, M. (2016). Creative Industry Within the European Regional Policy - Effect and Benefits. Knowledge for Market Use, 199-207.

Lee, M., Yun, J. J., Pyka, A., Won, D., Kodama, F., Schiuma, G., ... \& Zhao, X. (2018). How to respond to the fourth industrial revolution, or the second information technology revolution? Dynamic new combinations 
106 | QUANTIFICATION OF THE INTERDEPENDENCE OF INNOVATION ABILITY AND COMPETITIVENESS OF THE SOUTHEAST EUROPEAN COUNTRIES

between technology, market, and society through open innovation. Journal of Open Innovation: Technology, Market, and Complexity, 4(3), 21.

Peleckis, K. (2016). International business negotiation strategies based on bargaining power assessment: the case of attracting investments. Journal of Business Economics and Management, 17(6), 882-900.

Philbeck, T., \& Davis, D. (2019). The Fourth Industrial Revolution: Shaping a New Era. Journal of International Affairs, 72(1), 17-22.

Prisecaru, P. (2016). Challenges of the Fourth Industrial Revolution. Knowledge Horizons - Economic, 8(1), 57-62.

Schwab, K. (2016). Fourth Industrial Revolution. Geneva: World Economic Forum.

Schwab, K. (2018). The Global Competitiveness Report 2018. Geneva: World Economic Forum.

Schwab, K. (2019). The Global Competitiveness Report 2019. Geneva: World Economic Forum.

Sredojević, D. (2016). Inovacioni kapacitet privrede kao ograničavajući faktor unapređenja konkurentnosti zemalja Jugoistočne Evrope (Doktorska disertacija). Niš: Ekonomski fakultet, Univerzitet u Nišu.

World Economic Forum, GCI_4.0_2019_Dataset, Taken from: www3.weforum.org > docs > WEF_GCI_4.0_2019_Dataset.xlsx (10. 08. 2020).

Delivered: 01.09.2020.

Accepted: 26.01.2021. 